\title{
Effect of Supplemental Rumen Bypass Lysine and Methionine on Economics of Feeding in Growing Jaffrabadi Heifers
}

\author{
M.D. Odedra ${ }^{1 *}$, K. Ravikala ${ }^{2}$, K.S. Murthy ${ }^{3}$, A.R. Bhadaniya ${ }^{4}$ and S.N. Ghodasara ${ }^{5}$ \\ ${ }^{1}$ Department of Livestock Production Management, ${ }^{4}$ Department of Veterinary Pathology, \\ ${ }^{5}$ Department of Livestock Product Technology, College of Veterinary Science, \\ AU, Junagadh, India \\ ${ }^{2}$ Instructional Livestock Farm Complex, College of Veterinary Science, JAU, Junagadh, India \\ ${ }^{3}$ Cattle Breeding farm, Junagadh Agricultural University, Junagadh, India \\ *Corresponding author
}

\section{A B S T R A C T}

\begin{tabular}{|l|}
\hline Ke y w o r d s \\
$\begin{array}{l}\text { Economics, Heifers, } \\
\text { Jaffrabadi, Lysine, } \\
\text { Methionine }\end{array}$ \\
\hline Article Info \\
\hline $\begin{array}{l}\text { Accepted: } \\
\text { 15 July } 2018 \\
\text { Available Online: } \\
10 \text { August } 2018\end{array}$ \\
\hline
\end{tabular}

\section{Introduction}

Jaffrabadi buffalo heifers, a heavy breed of Saurashtra region of Gujarat state (adult BW $650 \mathrm{~kg}$ ), are bred at average body weight of $337 \mathrm{~kg}$ with age at first calving hovering around 50 to 55 months (Anonymous, 2011).

Manipulation of growth rate to attain an ADG of $500 \mathrm{~g}$ per day, can reduce AFC to around 40 months (Bhatti et al., 2007). Nutritional

\begin{abstract}
An experiment was conducted to evaluate incorporation of rumen protected LYS and MET on economics of fedding in Jaffrabadi buffalo heifers. Eighteen buffalo heifers of Cattle Breeding Farm, Junagadh Agricultural University were offered one of the dietary treatments for a period of 180 days: T1-DCP requirement met through concentrate mixture, T2-DCP requirement through cottonseed cake and concentrate mixture (50:50) and T3-In addition to DCP requirement through concentrate mixture with supplementation of rumen bypass LYS and MET @ $5.0 \mathrm{~g}$ and $2.5 \mathrm{~g} /$ day/animal respectively. Cost of feeding/day (Rs/day) was $48.13 \pm 4.18,45.99 \pm 2.01$ and $55.19 \pm 2.03$ in T1, T2 and T3, respectively, cost of feeding significantly $(\mathrm{P}<0.05)$ higher in $\mathrm{T} 3$ than $\mathrm{T} 1$ and $\mathrm{T} 2$. Cost of feeding (Rs/Kg body weight gain) was $99.81 \pm 13.49,87.66 \pm 4.06$ and $98.63 \pm 4.71$ for $\mathrm{T} 1$, $\mathrm{T} 2$ and $\mathrm{T} 3$, respectively, the differences being non-significant. Cost of feeding was higher in $\mathrm{T} 3$ due to supplementation of the rations with rumen by pass amino acids.
\end{abstract}




\section{Materials and Methods}

Eighteen Jaffrabadi Heifers (15 to 21 months) from Jaffrabadi buffalo herd of the Cattle Breeding Farm, Junagadh Agricultural University, Junagadh, were randomized and blocked into three groups of six each and were offered Protein requirement (ICAR, 1998) through (T1) commercial concentrate, (T2) protein requirement split through commercial concentrate and cottonseed cake (50:50) and (T3) commercial concentrate supplemented with rumen bypass LYS and MET @ 5.0 and $2.5 \mathrm{~g} / \mathrm{animal} / \mathrm{day}$ (commercially procured, brand name Metipearl \& Lysipearl from Kemin Industry Asia Ltd.), respectively, besides receiving $10 \mathrm{~kg}$ seasonal green fodder per animal and mature pasture grass hay offered ad.lib. Animals had access to fresh, clean drinking water.

The cost of feeding per animal was calculated from the data of feed intake and prevailing procurement price of individual feed ingredients. The average actual prices of feed on as such basis purchased during the experiment are given in Table 1. The cost of green and dry fodder was as per the rates decided by Junagadh Agricultural University.

\section{Results and Discussion}

Experimental duration was divided into thirteen periods. Mean body weight gains of experimental Jaffrabadi heifers during different phases of growth are given Table 2 .

Mean total cost of feeding/day was $48.13 \pm$ $2.07,45.99 \pm 2.01$ and $55.19 \pm 2.03$ (Rs./day) in T1, T2 and T3 respectively (Table 3). There was significant $(\mathrm{P}<0.05)$ difference during all the periods with regard to cost of feeding except during P2. During all these periods and in for the entire period T3 feeding regimen was significantly $(\mathrm{P}<0.05)$ higher than $\mathrm{T} 1$ and $\mathrm{T} 2$, which were at par. Supplementation of bypass amino acids (T3) was 14.67 per cent costlier compared to $\mathrm{T} 1$ and 20 per cent compared to $\mathrm{T} 2$.

However, with regard to the cost of feeding $\mathrm{Rs} / \mathrm{Kg}$ body weight gain (table 3) was $99.81 \pm$ $13.49,87.66 \pm 4.06$ and $98.63 \pm 4.71$ for $\mathrm{T} 1$, $\mathrm{T} 2$ and T3 respectively. Periodic differences were non-significant, except during P3. During $\mathrm{P} 3, \mathrm{~T} 1$ was significantly $(\mathrm{P}<0.05)$ higher than T3 and T2, though the cost of feeding /day was significantly $(\mathrm{P}<0.05)$ higher in $\mathrm{T} 3$.

This might be due to higher growth recorded in $\mathrm{T} 3$ during this period. $\mathrm{T} 3$ was at par with $\mathrm{T} 1$ and $\mathrm{T} 2$ with regard to cost of feeding / $\mathrm{kg}$ weight gain. However, cost / $\mathrm{kg}$ gain was lower by 12.51per cent in T2 compared to T3. The cost of feeding was higher in $\mathrm{T} 3$ due to supplementation of the rations with rumen by pass amino acids.

Table.1 The average actual prices of feeds on as such basis

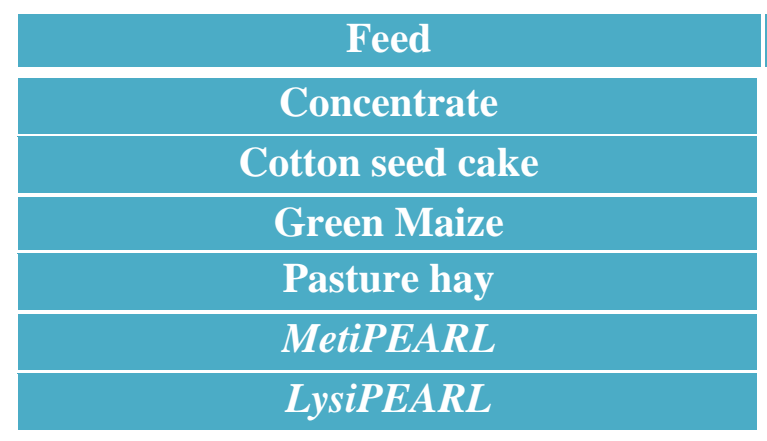

\begin{tabular}{|c|}
\hline Price $(\mathrm{Rs} / \mathrm{kg})$ \\
\hline 11.50 \\
\hline 14.00 \\
\hline 01.00 \\
\hline 02.60 \\
\hline 478.00 \\
\hline 292.00 \\
\hline
\end{tabular}


Table.2 Mean body weight (kgs) of growing Jaffrabadi buffalo heifers during different experimental periods $(n=6)$

\begin{tabular}{|l|c|c|c|c|c|c|}
\hline & T1 & T2 & T3 & S.Em. & C.D.at 5 \% & C.V. \% \\
\hline P0 & $259.20 \pm 3.98$ & $255.32 \pm 10.53$ & $257.45 \pm 11.41$ & 12.07 & NS & 11.49 \\
\hline P12 & $374.67 \pm 14.06$ & $382.67 \pm 16.35$ & $402.67 \pm 11.14$ & 14.02 & NS & 8.88 \\
\hline Overall & $115.47 \pm 4.35$ & $127.35 \pm 8.01$ & $145.22 \pm 3.50$ & 5.64 & 17.00 & 10.68 \\
\hline
\end{tabular}

Table.3 Total cost of feeding / day and mean total cost of feeding Rs/Kg body weight gain

\begin{tabular}{|c|c|c|c|c|c|c|c|}
\hline & T1 & T2 & T3 & S. Em. & C.D.at 5 \% & C.V. \% \\
\hline P1 & $39.21 \pm 2.11$ & $37.29 \pm 1.60$ & $44.47 \pm 1.77$ & 1.84 & 5.54 & 11.17 \\
\hline P12 & $56.26 \pm 2.24$ & $55.71 \pm 2.36$ & $66.03 \pm 1.95$ & 2.19 & 6.61 & 9.06 \\
\hline OVERALL & $48.13 \pm 2.07$ & $45.99 \pm 2.01$ & $55.19 \pm 2.03$ & 2.04 & 6.15 & 10.04 \\
\hline \multicolumn{7}{|c|}{ Mean total cost of feeding (Rs) / kg body weight gain } \\
\hline P1 & $77.81 \pm 15.27$ & $73.09 \pm 17.48$ & $100.01 \pm 37.28$ & 25.36 & NS & 74.27 \\
\hline P12 & $161.14 \pm 23.85$ & $148.64 \pm 14.81$ & $207.60 \pm 27.91$ & 22.86 & NS & 32.47 \\
\hline OVERALL & $99.81 \pm 13.49$ & $87.66 \pm 4.06$ & $98.63 \pm 4.71$ & 8.58 & NS & 22.03 \\
\hline
\end{tabular}

Rode et al., (1997) opined that RPAA supplemented cows produced increased milk at decreased cost. Driver, (2007) employed the strategy of reducing dietary $\mathrm{CP}$ and obtained a return on investment (ROI) ranging from 1.1 to 5.5 with an average of 3.35:1.Divya et al., (2009) obtained better growth rate at a lower cost by increased UDP in the ration.

Present experiment was conducted on growing Jaffrabadi heifers and any effort to reduce age at first conception / AFC should be viewed as an economic gain. As these are non-productive animals only growth should be considered as an advantage which was significantly $(\mathrm{P}<0.05)$ higher in $\mathrm{T} 3$ group of heifers.

Feeding regimen based on supplemental feeding of rumen bypass LYS and MET were costlier but cost was justified in the long run as the heifers conceive at an early age thus reducing $\mathrm{AFC}$ and earlier economic returns in the form of milk production to dairy farmers.

\section{References}

Anonymous, 2011. Annual progress report, Cattle Breeding Farm JAU, Junagadh, India.

Bhatti, S. A., Sarwar, M., Khan, M. S. and Hussain, S. M. 2007. Reducing the age at first calving through nutritional manipulations in dairy buffaloes and cows. Pakistan Vet. J., 2007, 27 (1): 4247.

Divya, Tiwari, D. P. and Anil Kumar. 2009. Effect of different levels of undegradable dietary protein and plane of nutrition on the performance of growing crossbred heifers. Indian $J$. Anim. Sci. 79 (5): 498-503.

Driver, S. 2000. From concept to practice experience in the USA. International Amino Acid Seminar - Belgium.

ICAR. 1998 Nutrient requirement for livestock and poultry. Indian Council of Agricultural Research, Krishi Bhavan, New Delhi. 
Rode, L. M., Julien, W. E., Sato, H., Fujieda, T. and Suzuki, H. 1997. Rumen protected amino acids (RPAA) supplementation pre and post-partum in commercial herds. J. Dairy Sci., 82 (1): $121-124$.

\section{How to cite this article:}

Odedra, M.D., K. Ravikala, K.S. Murthy, A.R. Bhadaniya and Ghodasara, S.N. 2018. Effect of Supplemental Rumen Bypass Lysine and Methionine on Economics of Feeding in Growing Jaffrabadi Heifers. Int.J.Curr.Microbiol.App.Sci. 7(08): 2550-2553.

doi: https://doi.org/10.20546/ijcmas.2018.708.261 